\title{
PENGARUH HARGA, DISTRIBUSI DAN PROMOSI TERHADAP KEPUTUSAN PEMBELIAN OBAT BATUK KOMIX
}

\author{
Rini Ardista \\ Sekolah Tinggi Ilmu Ekonomi Tribuana Bekasi \\ Riniardista27@gmail.com
}

\begin{abstract}
Penelitian ini merupakan penelitian sampel sederhana. Metode penelitian yang digunakan dalam penelitian ini adalah metode deskriptif analisis. Teknik analisis data yang digunakan adalah teknik analisis korelasi dan teknik analisis jalur. Teknik analisis korelasi untuk mengetahui keeratan hubungan antar variabel bebas terhadap variabel terikatnya. Perangkat lunak yang digunakan untuk mengolah dan menganalisis data penelitian ini adalah SPP versi 23.0. Berdasarkan hasil analisis uji t, diketahui nilai $t_{\text {hitung }}<t_{\text {tabel }}$ yaitu sebesar 0,014 < 2,012 dengan signifikansi 0,989, sehingga keputusan yang diambil adalah Ho diterima dan Ha ditolak. Hasil ini menunjukkan bahwa harga secara parsial tidak memberikan pengaruh signifikan terhadap keputusan pembelian pada PT Enseval Putera Berdasarkan hasil analisis uji $t$, diketahui nilai $t_{\text {hitung }}>t_{\text {tabel }}$ yaitu sebesar 4,792>2,012 dengan signifikansi 0,000, sehingga keputusan yang diambil adalah Ho ditolak dan Ha diterima. Hasil ini menunjukkan bahwa distribusi secara parsial berpengaruh signifikan terhadap keputusan pembelian pada PT Enseval Putera Berdasarkan hasil analisis uji $t$, diketahui nilai $t_{\text {hitung }}<t_{\text {tabel }}$ yaitu sebesar 1,143<2,012 dengan signifikansi 0,259, sehingga keputusan yang diambil adalah Ho diterima dan Ha ditolak. Hasil ini menunjukkan bahwa promosi secara parsial tidak memberikan pengaruh signifikan terhadap keputusan pembelian pada PT Enseval Putera Berdasarkan hasil analisis uji F, diketahui Fhitung $>$ Ftabel $(13,658>2,574)$ dengan nilai signifikansi 0,000, sehingga keputusan yang diambil adalah Ho ditolak dan Ha diterima. Hasil ini menunjukkan bahwa seluruh variabel bebas (harga, distribusi dan promosi) berpengaruh secara simultan atau bersama-sama terhadap keputusan pembelian pada PT Enseval Putera
\end{abstract}

Kata kunci: Harga, Distribusi, Promosi dan Keputusan Pembelian.

\begin{abstract}
This research is a simple random sampling. The research method used in this research is deskriptive analysis method. The data analysis technique used is the technique of correlation analysis and path analysis teqniques. Correlation analysis teqniques to determine the relationship between variables, while the technique of path analysis to determine how much influence the independent variables on the dependent variable. The software used to process and analyze the data of this study was SPSS version 23.0. Based on the result of t test analysis, it is known that $t_{\text {count }}<t_{\text {table }}$ is $0,014<2,012$ with significance 0,989, so decision taken is Ho accepted and Ha rejected. These results indicate that the price partially does not give significant effect on Purchase Decisions at PT Enseval Putera Based on the result of t test analysis, it is known that $t_{\text {count }}>t_{\text {table }}$ is 4,792>2,012 with significance 0,000, so the decision taken is Ho rejected and Ha accepted. These results indicate that partially distribution has significant effect on Purchase Decisions at PT Enseval Putera Based on the result of $t_{\text {test }}$ analysis, it is known that $t_{\text {count }}>t_{\text {table }}$ is 1,143<2,012 with significance 0,259, so decision taken is Ho accepted and Ha rejected. These results indicate that the promotion partially does not give significant effect on Purchase Decisions at PT Enseval Putera. Based on the result of $F$ test analysis, it is known that Fcount> Ftable $(13,658>2,574)$ with significance value 0,001, so that decision taken is Ho refused and Ha accepted. These results indicate that all independent variables (price, distribution and promotion) influence simultaneously or together to give to the performance of Purchase Decisions at PT Enseval Putera
\end{abstract}

Keywords: Price, Distribution, Promotions and Purchase Decisions. 


\section{PENDAHULUAN}

Obat batuk komix salah satu obat yang mudah ditemukan di mana saja. Penyebarannya sudah ada di Indonesia mulai dari di apotek hingga toko obat yang menyediakan kebutuhan sehari-hari. Komix biasa juga dikenal sebagai obat batuk yang bagus karena memiliki kandungan yang pas untuk mengatasi batuk. Di dalamnya terdapat ekstrak bahan yang berguna untuk meredakan masalah batuk. Bukan hanya itu, komix pun punya nilai lebih lain. Varian rasa dan kandungan di dalamnya pun beragam, sehingga konsumen bisa memilih yang pas sesuai kebutuhan maupun selera masing-masing. Contoh termudah adalah keberadaan tiga jenis obat batuk komix, yakni komix jahe, komix jeruk nipis, serta komix peppermint. Setiap jenis memiliki kandungan yang sesuai dengan namanya masing-masing. Selain itu komix juga mengeluarkan komix Herbal dan komix lo han kuo, yang keduanya memiliki manfaat dan kandungannya masing-masing. Di samping adanya persaingan dari produk merek lain yang meliputi variasi dan inovasinya, para pemain (produsen obat) juga tak segan-segan menggelontorkan belanja iklan yang lebih besar dibanding tahun-tahun sebelumnya. Dimana dua pengiklan terbesar di TV adalah komix dan OBH Combi (Octavia, 2014:1).

Keputusan pembelian adalah suatu kegiatan membeli sejumlah barang dan jasa, yang dipilih berdasarkan informasi yang didapat tentang produk dan segera disaat kebutuhan dan keinginan muncul, dan kegiatan ini menjadi informasi untuk pembelian selanjutnya. Menurut Kotler (2012:157), perilaku keputusan pembelian mengacu pada perilaku pembelian akhir dari konsumen, baik individual, maupun rumah tangga yang membeli barang dan jasa untuk konsumsi pribadi. Menurut Kotler dan Keller (2012:67), harga adalah suatu elemen bauran pemasaran yang menghasilkan pendapatan, elemen lain menghasilkan biaya.

Harga merupakan elemen termudah dalam program pemasaran untuk disesuaikan, fitur produk, saluran, dan bahkan komunikasi membutuhkan banyak waktu.. Selain desain produk, harga merupakan variabel yang dapat dikendalikan dan menentukan diterima atau tidaknya suatu produk oleh konsumen. Murah atau mahalnya harga suatu produk sangat relatif sifatnya. Untuk mengatakannya perlu terlebih dahulu dibandingkan dengan harga produk serupa yang diproduksi atau dijual perusahaan lain. Perusahaan perlu memonitor harga yang ditetapkan oleh para pesaing agar harga yang ditentukan oleh perusahaan tidak terlalu tinggi atau sebaliknya.

Menurut Assauri (2012:23), distribusi (penyaluran) adalah kegiatan penyampaian produk sampai ke tangan si pemakai atau konsumen pada waktu yang tepat. Distribusi merupakan masalah lain yang akan dihadapi perusahaan pada saat produk selesai diproses. Distribusi ini menyangkut cara penyampaian produk ke tangan konsumen. Manajemen pemasaran mempunyai peranan dalam mengevaluasi penampilan para penyalur. Bila perusahaan merencanakan suatu pasar tertentu, yang pertama kali dipikirkan adalah siapa yang akan ditunjuk sebagai penyalur di sana, atau berapa banyak yang bersedia untuk menjadi penyalur di daerah itu.

Promosi merupakan salah satu komponen dari bauran pemasaran (marketing mix). Fungsi promosi dalam bauran pemasaran adalah untuk mencapai berbagai tujuan komunikasi dengan konsumen. Menurut Rangkuti (2012:50), "Promosi adalah kegiatan penjualan dan pemasaran dalam rangka menginformasikan dan mendorong permintaan terhadap produk, jasa, dan ide dari perusahaan dengan cara memengaruhi konsumen agar mau membeli produk dan jasa yang dihasilkan oleh perusahaan." Promosi merupakan salah satu faktor penentu keberhasilan suatu program pemasaran. Betapapun berkualitasnya suatu produk, bila konsumen belum pernah mendengarnya dan tidak yakin bahwa produk itu akan berguna bagi mereka, maka mereka tidak akan pernah membelinya.

\section{KAJIAN PUSTAKA DAN PEGEMBANGAN HIPOTESIS Harga}

Harga merupakan unsur bauran pemasaran yang sifatnya fleksibel dimana setiap saat dapat berubah menurut waktu dan tempatnya. Harga bukan hanya angka-angka yang tertera dilabel suatu kemasan atau rak toko, tapi harga mempunyai banyak bentuk dan melaksanakan banyak fungsi. Sewa rumah, uang sekolah, ongkos, upah, bunga, tarif, biaya penyimpanan dan gaji semuanya merupakan harga yang harus anda bayar untuk mendapatkan barang atau jasa. Dalam situasi tertentu para konsumen sangatlah sensitif terhadap harga, sehingga harga yang relatif tinggi dibanding para pesaingnya dapat mengeliminasi produk dari pertimbangan konsumen. Akan tetapi, dalam kasus lainnya harga dapat dipergunakan sebagai 
indikator pengganti kualitas produk, dengan hasil bahwa harga yang lebih tinggi dipandang positif oleh segmen tertentu. Kemudian harga produk dapat memberikan baik pengaruh positif maupun negatif terhadap konsumen. Ini merupakan konsep penting yang harus diingat oleh para manajer.

Dari sudut pandang produsen harga merupakan komponen yang berpengaruh langsung terhadap laba perusahaan dalam artian merupakan pendapatan. Sementara itu, dari sudut pandang konsumen harga sering kali digunakan sebagai indikator nilai bilamana harga tersebut dihubungkan dengan manfaat yang dirasakan atas suatu produk atau dalam arti kata harga merupakan pengorbanan bagi konsumen dalam mendapatkan suatu produk. Namun secara sederhana harga dapat diartikan sebagai sejumlah uang (satuan moneter) dan atau aspek lain (non moneter) yang mengandung kegunaan tertentu yang diperlukan untuk mendapatkan suatu produk/jasa.

Dalam menetapkan harga suatu produk, harus dipertimbangkan faktor-faktor yang mempengaruhi kepekaan konsumen terhadap harga tersebut. Menurut Rambat (2013) terdapat beberapa faktor yang mempengaruhi kepekaan harga, yaitu:

1. Pengaruh nilai unik (unique-value effect), para pembeli akan kurang peka terhadap harga jika produk tersebut lebih bersifat unik.

2. Pengaruh kesadaran atas produk pengganti (subtitusi-awaereness effect), para pembeli semakin kurang peka terhadap harga jika mereka tidak menyadari adanya produk pengganti.

3. Pengaruh perbandingan yang sulit (difficult-comparison effect), para pembeli semakin kurang peka terhadap harga jika mereka tidak dapat dengan mudah membandingkan mutu barang pengganti.

4. Pengaruh pengeluaran total (total-expansiture effct), pembeli semakin kurang peka terhadap harga jika pengeluaran tersebut semakin rendah dibandingkan pendapatan totalnya.

5. Pengaruh manfaat akhir, para pembeli semakin kurang peka terhadap harga jika pengeluaran tersebut semakin kecil dibandingkan biaya total produk akhir.

6. Pengaruh biaya bersama (shared-cost effect), para pembeli semakin kurang peka terhadap harga jika sebagian biaya itu ditanggung pihak lain.

7. Pengaruh investasi tertanam (sunk investment effect), para pembeli semakin kurang peka terhadap harga jika produk tersebut digunakan bersama dengan aktiva yang telah dibeli sebelumnya.

8. Pengaruh mutu-harga (price-quality effect), para pembeli akan semakin kurang peka terhadap harga jika produk tersebut dianggap memilki mutu, prestise atau eksklusivitas yang lebih.

9. Pengaruh persediaan (inventory effect), pembeli kurang sensitif terhadap harga bila mereka tidak dapat menyimpan produk tersebut.

Harga yang diinginkan konsumen adalah terjangkau, bersaing dengan merek lain sertasesuai dengan kualitasnya.

\section{Distribusi}

Menurut Hamaizar Zaharuddin (2012:32). Distribusi adalah himpunan organisasi yang saling bergantung yang terlibat dalam proses untuk membuat produk atau jasa yang siap untuk dikonsumsi atau digunakan oleh konsumen atau pengguna industrial. Menurut Delliyanti (2012:23), distribusi (penyaluran) adalah kegiatan penyampaian produk sampai ke tangan si pemakai atau konsumen pada waktu yang tepat. Menurut Kotler dan Keller (2012:23). Komponen distribusi dalam bauran pemasaran adalah: Saluran pemasaran, cakupan pasar, pengelompokkan, lokasi, persediaan, transportasi.

Distribusi juga dapat diartikan sebagai pencakupan pasar, struktur eceran dan grosir, saluran yang dipergunakan untuk membawa produk ke pasarnya (Abdullah dan Tantri, 2012:3).

Menurut David (2013:45). Untuk barang dan jasa konsumen, pencapaian tingkat ketersediaan produk yang diinginkan merupakan masalah pemilihan dan mendapatkan kerjasama dari jumlah outlet eceran yang tepat. Ada tiga strategi, yaitu distribusi insentif, distribusi eksklusif dan distribusi selektif:

1. Distribusi Insentif: Strategi ini menggunakan jumlah pengecer maksimum dan yang paling tepat untuk produk-produk dengan keterlibatan rendah dan sering dibeli, seperti permen, minuman ringan, deodoran dan pisau cukur.

2. Distribusi Eksklusif: Strategi ini hanya mengandalkan satu pengecer atau penyalur di setiap wilayah geografis tertentu. Cara ini paling tepat ketika produk merupakan barang khusus atau belanja dengan keterlibatan tinggi.

3. Distribusi Selektif: Yaitu cara ini merupakan penengah dari kedua cara di atas karena menggunakan lebih dari satu namun tidak semua pengecer di dalam wilayah geografis tertentu. 
Strategi ini lebih tepat digunakan untuk barang-barang belanja. Kebanyakan merek mobil didistribusikan dengan cara ini.

\section{Promosi}

Promosi berasal dari kata promote dalam bahasa Inggris yang diartikan sebagai mengembangkan atau meningkatkan. Promosi merupakan salah satu komponen dari bauran pemasaran (marketing mix). Fungsi promosi dalam bauran pemasaran adalah untuk mencapai berbagai tujuan komunikasi dengan konsumen.

Pengertian promosi menurut Kotler dan Armstrong (2012:76), "Promotion means activities that communicate the merits of the product and persuade target customers to buy it", artinya promosi merupakan kegiatan yang mengomunikasikan manfaat dari sebuah produk dan membujuk target konsumen untuk membeli produk tersebut. Menurut Simamora (2012:50), "Promosi adalah kegiatan penjualan dan pemasaran dalam rangka menginformasikan dan mendorong permintaan terhadap produk, jasa, dan ide dari perusahaan dengan cara memengaruhi konsumen agar mau membeli produk dan jasa yang dihasilkan oleh perusahaan."

Dari defenisi diatas dapat disimpulkan bahwa promosi penjulan memberikan manfaat langsung kepada konsumen pada saat mereka melakukan pembelian. Promosi penjulan dapat berupa memberikan diskon/potongan harga,kupon, konter, undian, harga premi dan sebagainya.

Promosi penjualan tidak lepas dari alat-alat promosi penjualan, sehingga alat-alat promosi penjualan ini sangat penting dalam promosi penjualan, setiap alat memiliki manfaat berbeda, sehingga pemasar harus jeli dalam menggunakan alat-alat ini, agar sesuai dengan strategi dan target yang ingin di capai. Suatu produk apabila ingin dikenal oleh masyarakat, maka harus dipromosikan. Banyak cara yang dapat dilakukan untuk melakukan promosi, diantara melalui iklan, brosur dan papan nama. Dengan demikian semakin sering dipromosikan suatu produk, maka keputusan konsumen untuk melakukan pembelian semakin tinggi.

\section{Keputusan Pembelian}

Keputusan pembelian adalah suatu kegiatan membeli sejumlah barang dan jasa, yang dipilih berdasarkan informasi yang didapat tentang produk, dan segera disaat kebutuhan dan keinginan muncul, dan kegiatan ini menjadi informasi untuk pembelian selanjutnya. Menurut Kotler dan Armstrong (2012:157), "perilaku keputusan pembelian mengacu pada perilaku pembelian akhir dari konsumen, baik individual, maupun rumah tangga yang membeli barang dan jasa untuk konsumsi pribadi".

Pengambilan keputusan pembelian konsumen berbeda-beda tergantung jenis keputusan pembeliannya. Menurut Kotler (2012:221). Ada empat jenis perilaku pembelian konsumen berdasarkan tingkat keterlibatan pembeli dan tingkat perbedaan merek, yaitu:

\section{Perilaku pembelian kompleks}

Konsumen melakukan perilaku pembelian kompleks ketika mereka sangat terlibat dalam pembelian dan merasa ada perbedaan yang signifikan antar merek. Pada tahap ini, pembeli akan melewati proses pembelajaran, mulamula mengembangkan keyakinan tentang produk, lalu sikap, dan kemudian membuat pilihan pembelian yang dipikirkan masak-masak.

\section{Perilaku pembelian pengurangan disonansi (ketidaknyamanan)}

Perilaku pembelian pengurangan disonansi terjadi ketika konsumen sangat terlibat dalam pembelian yang mahal, jarang dilakukan, atau beresiko, tetapi hanya melihat sedikit perbedaan antar merek. Setelah pembelian, konsumen mungkin mengalami ketidaknyamanan pasca pembelian ketika mereka mengetahui kerugian tertentu dari merek yang dibeli atau mendengar hal-hal menyenangkan tentang merek yang tidak dibeli. Untuk menghadapi disonansi semacam itu, komunikasi pasca penjualan yang dilakukan pemasar harus memberikan bukti dan dukungan untuk membantu konsumen merasa nyaman dengan pilihan merek mereka.

\section{Perilaku pembelian kebiasaan}

Perilaku pembelian kebiasaan terjadi ketika dalam keadaan keterlibatan konsumen yang rendah dan sedikit perbedaan merek. Konsumen hanya mempunyai sedikit keterlibatan dalam kategori produk ini, mereka hanya pergi ke toko dan mengambil satu merek. Jika mereka terus mengambil merek yang sama, hal ini lebih merupakan kebiasaan daripada loyalitas yang kuat terhadap sebuah merek. Konsumen tidak secara ekstensif mencari informasi tentang merek, mengevaluasi karakteristik merek, dan mempertimbangkan keputusan tentang merek yang akan dibeli. Sebagai gantinya, 
konsumen menerima informasi secara pasif ketika merek menonton televisi atau membaca majalah. Pengulangan iklan menciptakan kebiasaan akna suatu merek dan bukan keyakinan merek. Konsumen tidak membentuk sikap yang kuat terhadap sebuah merek, mereka memilih merek karena terbiasa dengan merek tersebut, konsumen mungkin tidak mengevaluasi pilihan bahkan setelah melakukan pembelian..

\section{Perilaku pembelian mencari keragaman}

Perilaku pembelian mencari keragaman dalam situasi yang mempunyai karakter keterlibatan konsumen rendah, tetapi anggapan perbedaan merek yang signifikan. Dalam kasus ini, konsumen sering melakukan banyak pertukaran merek. Pemimpin pasar akan mencoba mendorong perilaku pembeli kebiasaan dengan mendominasi ruang rak, membuat rak tetap penuh, dan menjalankan iklan untuk mengingatkan konsumen sesering mungkin. Perusaahan penantang akan mendorong pencarian keragaman dengan menawarkan harga yang lebih murah, kesepakatan kupon khusus, sampel gratis, dan iklan yang menampilkan alasan untuk mencoba sesuatu yang baru.

Produk mencerminkan kombinasi antara produk dan jasa yang ditawarkan kepada konsumen. Harga adalah sejumlah uang yang harus dibayar untuk mendapatkan produk. Distribusi mencerminkan kegiatan yang dilakukan perusahaan yang membuat barang tersedia untuk konsumen. Promosi adalah komunikasi dalam mempengaruhi dan membujuk konsumen untuk membeli. Sedangkan tiga bauran tambahan untuk jasa yaitu proses merupakan penyampaian jasa tersebut. Orang adalah karyawan perusahaan, pengguna jasa itu sendiri, pengguna jasa lainnya. Bukti fisik menggambarkan semua fasilitas fisik yang merupakan buatan manusia.

\section{Kerangka Pikir}

Kerangka berpikir adalah sebuah gambaran berupa konsep yang didalamnya menjelaskan tentang hubungan antara satu variabel dengan variabel lainnya, bisa diartikan bahwa kerangka pemikiran ini merupakan penjelasan sementara mengenai hubungan yang dijadikan sebagai permasalahan pada topik penelitian.

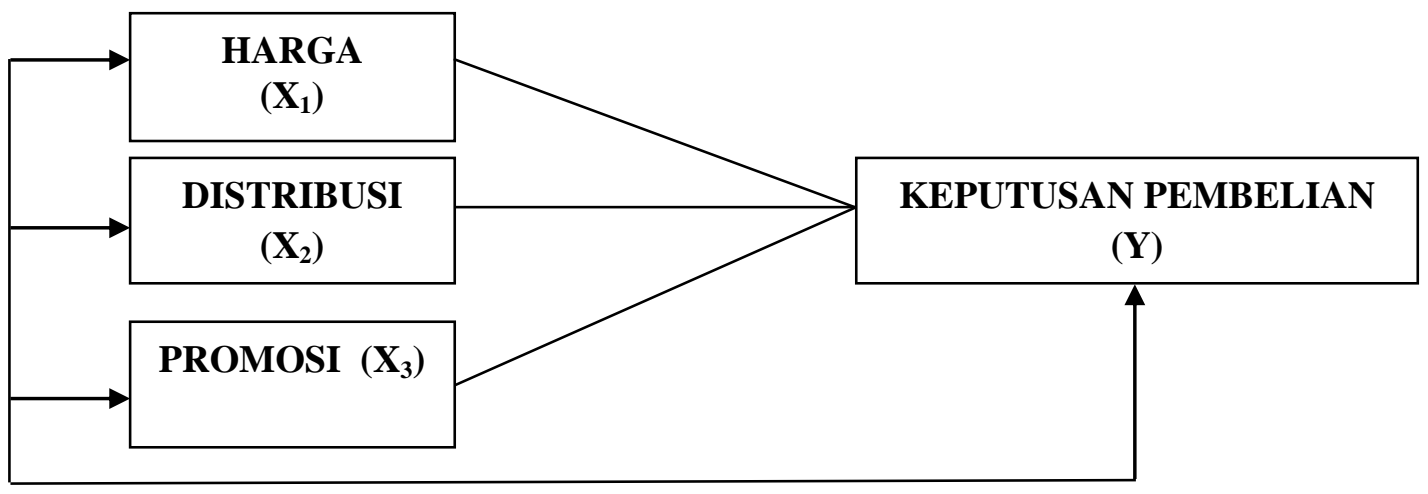

\section{Hipotesa}

Hipotesa 1

$\mathrm{Ho}_{1}$ : Diduga tidak ada pengaruh signifikan harga terhadap keputusan pembelian.

$\mathrm{Ha}_{1}$ : Diduga ada pengaruh signifikan harga terhadap keputusan pembelian.

Hipotesa 2

$\mathrm{Ho}_{2}$ : Diduga tidak ada pengaruh signifikan distribusi terhadap keputusan pembelian.

$\mathrm{Ha}_{2}$ : Diduga ada pengaruh signifikan distribusi terhadap keputusan pembelian.

Hipotesa 3

$\mathrm{Ho}_{3}$ : Diduga tidak ada pengaruh signifikan promosi terhadap keputusan pembelian.

$\mathrm{Ha}_{3}$ : Diduga ada pengaruh signifikan promosi terhadap keputusan pembelian. 
Hipotesa 4

$\mathrm{Ho}_{4}$ : Diduga tidak ada pengaruh signifikan antara harga, distribusi dan promosi secara bersama-sama terhadap keputusan pembelian.

$\mathrm{Ho}_{4}$ : Diduga ada pengaruh signifikan antara harga, distribusi dan promosi secara bersama-sama terhadap keputusan pembelian.

\section{METODE PENELITIAN}

Metode adalah prosedur atau cara untuk mengetahui sesuatu, yang mempunyai langkah sistemaris. Penelitian pada umumnya bertujuan untuk mempunyai dan menemukan sesuatu masalah atau fenomena yang terjadi pada objek. Menurut Sugiyono (2015:2) "metode penelitian pada dasarnya merupakan cara aamiah untuk mendapatkan data dengan tujuan dan kegunaan tertentu". Dalam melakukan penelitian diperlukan langkah-langkah yang tersusun secara sistematis untuk mendapatkan data sehingga tujuan penelitian dapat tercapai.

Menurut Sugiyono (2015:80) "populasi adalah wilayah generalisasi yang terdiri atas obyek atau subyek yang mempunyai kualitas dan karakteristik tertentu yang ditetapkan oleh peneliti untuk dipelajari kemudian ditarik kesimpulannya". Jadi populasi bukan hanya orang, tetapi juga objek dan benda-benda alam yang lain. Populasi juga bukan sekedar jumlah yang ada pada objek atau subjek yang dipelajari, tetapi meliputi seluruh karakteristik atau sifat yang dimiliki oleh subjek atau objek itu. Populasi dari penelitian ini adalah konsumen tetap PT Enseval Putera yang berjumlah 50 orang.

Menurut Sugiyono (2015:81), "sampel adalah bagian dari jumlah dan karakteristik yang dimiliki oleh populasi tersebut". Bila terdapat populasi yang besar dan peneliti tidak mungkin mempelajari semua yang ada pada populasi, misalnya karena keterbatasan dana, tenaga dan waktu, maka peneliti dapat menggunakan sampel yang di ambil dari populasi itu.

Dalam penelitian ini peneliti menggunakan probability sampling, yakni teknik pengambilan sampel yang memberikan peluang yang sama bagi setiap unsur (anggota) populasi untuk dipilih menjadi anggota sampel. Teknik ini meliputi sampel random sampling, disproportionate stratified random sampling, disproportionate stratified random sampling, cluster sampling (area sampling). Peneliti menggunakan probability sampling dengan jenis simple random sampling, yakni cara pengambilan secara acak tanpa memperhatikan strata (tingkatan) dalam anggota populasi tersebut. Simple random sampling dikatakan simple (sederhana) karena pengambilan anggota sampel dari populasi dilakukan secara acak tanpa memperhatikan strata yang ada dalam populasi itu.

\section{Tempat Penelitian}

Penelitian ini dilaksanakan pada perusahaan milik swasta yang bergerak dalam bidang distributor farmasi yaitu PT Enseval Putera J1. Srengseng Raya No.8, Srengseng, Kembangan, Jakarta Barat.

\section{Variabel Penelitian}

Variabel merupakan segala sesuatu yang akan menjadi objek pengamatan dalam penelitian yang merupakan suatu konsep yang mempunyai variasi nilai.

Variabel dalam penelitian ini didefinisikansecara jelas sehingga tidak menimbulkan pergantian ganda. Dalam penelitian ini terdapat dua macam variabel, yaitu variabel terikat (dependent variable) atau variabel yang terdiri dari variabel bebas (independent variabel). Peneliti menggunakan 2 variabel yang akan diteliti, yaitu:

1. Variabel $\mathrm{X}_{1}$ adalah harga yaitu sejumlah nilai yang ditukarkan oleh konsumen dengan manfaat dari memiliki atau mempergunakan barang atau jasa yang diperoleh dari PT Enseval Putera

2. Variabel $\mathrm{X}_{2}$ adalah distribusi yaitu salah satu alat yang digunakan oleh PT Enseval Putera untuk mencapai tujuan penjualan dimana produk yang telah siap untuk dijual memerlukan penyaluran dari status kepemilikan produsen ke konsumen.

3. Variabel $\mathrm{X}_{3}$ adalah promosi yaitu suatu usaha atau cara yang dilakukan oleh PT Enseval Putera untuk mempengaruhi seseorang atau organisasi agar dapat terjadi pertukaran atau pembelian.

4. Variabel Y adalah keputusan pembelian konsumen pada produk komix di PT Enseval Putera

\section{Teknik Analisis Data}

Analisis data dalam penelitian ini dimulai dengan menguji validitas dan reliabilitas instrument penelitian, yang berupa item-item pertanyaan dalam kuisioner.Dalam kuisioner tersebut digunakan skala 
Likert untuk mengukur sikap, pendapat dan persepsi seseorang atau sekelompok orang tentang fenomena sosial. Dengan skala Likert, maka variabel yang akan diukur dijabarkan menjadi indikator variabel. Kemudian indikator tersebut dijadikan sebagai titik tolak untuk menyusun item-item instrument yang dapat berupa pernyataan atau pertanyaan. Jawaban dari setiap item instrument yang menggunakan skala Likert mempunyai gradasi dari sangat positif sampai sangat negatif.Setelah itu, analisis dilanjutkan dengan menggunakan uji regresi linear berganda, dimana variabel terikatnya ( $\mathrm{Y}$ ) adalah keputusan pembelian dan variabel bebasnya adalah harga $\left(\mathrm{X}_{1}\right)$, distribusi $\left(\mathrm{X}_{2}\right)$ dan promosi $\left(\mathrm{X}_{3}\right)$.

\section{- Uji Validitas}

Validitas menunjukkan sejauh mana suatu alat pengukur itu mengukur apa yang ingin diukur. Dalam hal ini peneliti menggunakan kuisioner di dalam pengumpulan data, kuisioner yang disusunnya harus mengukur apa yang ingin diukurnya. Setelah kuisioner tersebut tersusun dan teruji validitasnya, dalam praktek belum tentu data yang dikumpulkan adalah data yang valid. Banyak hal-hal lain yang akan mengurangi validitas data, misalnya apakah si pewawancara yang mengumpulkan data betulbetul mengikuti petunjuk yang telah ditetapkan oleh kuisioner. Selain itu, validitas data akan ditentukan oleh keadaan responden sewaktu diwawancarai. Bila sewaktu menjawab semua pertanyaan ternyata semua responden merasa bebas tanpa ada rasa malu atau rasa takut, maka data yang diperoleh akan valid dan reliabel begitupun sebaliknya.

Variabel yang diukur adalah variabel harga $\left(\mathrm{X}_{1}\right)$, distribusi $\left(\mathrm{X}_{2}\right)$ dan promosi $\left(\mathrm{X}_{3}\right)$ sebagai variabel bebas dan keputusan pembelian $(\mathrm{Y})$ sebagai variabel terikat dengan kriteria keputusan :

Jika $r$ hitung $\geq r$ tabel, maka butir soal yang diuji dinyatakan valid

Jika $r$ hitung $<\mathrm{r}$ tabel, maka butir soal yang diuji dinyatakan tidak valid

\section{- Uji Reliabilitas}

Uji reliabilitas menurut Priyatno (2013:30) adalah "suatu alat pengukur dikatakan reliabel bila alat itu dalam mengukur suatu gejala pada waktu yang berlainan senantiasa menunjukkan hasil yang sama". Jadi alat yang reliabel secara konsisten memberi hasil ukuran yang sama. Metode uji reliabilitas yang sering digunakan adalah Cronbach's Alpha.

\section{- Koefisien Korelasi}

Analisis korelasi berguna untuk menentukan suatu besaran yang menyatakan bagaimana kuat hubungan suatu variabel dengan variabel lain. Jadi tidak mempersoalkan apakah suatu variabel tertentu tergantung kepada variabel lain. Simbol dari besaran korelasi adalah $r$ yang disebut koefisien korelasi sedangkan simbol parameternya $\rho$ (dibaca rho). Uji korelasi dilakukan dengan menggunakan rumus uji korelasi product momentpearson:

\section{- Analisis Regresi Berganda}

Setelah validitas dan reliabilitas data diuji, maka tahap selanjutnya adalah melakukan pengujian dengan regresi berganda.Analisis regresi linier berganda digunakan untuk mengetahui pengaruh antara dua atau lebih variabel bebas dengan satu variabel terikat.Perbedaan dengan regresi linier sederhana yaitu terletak pada jumlah variabel bebasnya. Di mana regresi linier sederhana hanya menggunakan satu variabel bebas sedangkan regresi linier berganda menggunakan dua atau lebih variabel bebas yang dimasukkan dalam model regresi.Analisis ini juga untuk memprediksikan nilai dari variabel terikat apabila nilai variabel bebas mengalami kenaikan atau penurunan, dan untuk mengerahui arah hubungan antara varibel bebas dengan variabel terikat apakah masing-masing variabel bebas berhubungan positif atau negatif.

\section{- Uji Asumsi Klasik}

Uji asumsi klasik merupakan uji prasyarat jika anda menggunakan analisis regresi linier. Uji ini antara lain adalah uji normalitas residual, uji multikolinearitas, uji heteroskedastisitas, dan uji autokorelasi. Jika asumsi tersebut dilanggar, misal model regresi tidak normal, terjadi multikolinearitas, terjadi heteroskedastisitas atau terjadi autokorelasi.Maka hasil analisis regresi dan pengujian seperti uji t dan uji F menjadi tidak valid atau bias. Berikut akan dibahas masing-masing uji asumsi klasik regresi sebagai berikut: 
1. Uji Normalitas Residual

Uji normalitas residual digunakan untuk menguji apakah data residual terdistribusi secara normal atau tidak. Residual merupakan nilai sisa atau selisih antara nilai variabel terikat (Y) dengan variabel terikat hasil analisis regresi (Y'). Model regresi yang baik adalah yang baik adalah yang memiliki data residual yang terdistribusi secara normal. Dua cara yang digunakan dalam penelitian ini dalam menguji normalitas residual, yaitu dengan analisis grafik (normal P-P plot) regresi dan Uji One Sample Kolmogorov-Smirnov

2. Uji Multikolinearitas

Multikolinearitas adalah keadaan di mana terjadi hubungan linear yang sempurna atau mendekati sempurna antarvariabel terikat dalam model regresi.Suatu model regresi dikatakan mengalami multikolinearitas jika ada fungsi linear yang sempurna pada beberapa atau semua variabel dalam fungsi linear, Priyatno (2013:56). Dan hasilnya sulit didapatkan pengaruh antara variabel bebas dan variabel terikat.Model regresi yang baik seharusnya tidak terjadi korelasi di antara variabel bebas.

3. Uji Heteroskedastisitas

Heteroskedastisitas menurut Priyatno (2013:62) adalah "keadaan di mana terjadi ketidaksamaan varian dari residual untuk semua pengamatan pada model regresi.Model regresi yang baik adalah tidak terjadi masalah heteroskedastisitas". Ada beberapa metode yang bisa digunakan untuk uji heteroskedastisitas yaitu Spearman's Rho testing, glejser testing, dan grafik regresi. Dalam penelitian ini penulis menggunakan metode grafik, yaitu dengan melihat pola titik-titik pada scatterplot regresi. Jika titik-titik menyebar dengan pola yang tidak jelas di atas dan di bawah angka 0 pada sumbu Y, maka tidak terjadi masalah heteroskedastisitas.

\section{- Analisis koefisien determinasi (Adjusted $\mathbf{R}^{2}$ )}

Analisis determinasi digunakan untuk mengetahui persentase sumbangan pengaruh variabel bebas secara bersama-sama terhadap variabel terikat. Hasil analisis determinasi dapat dilihat pada output moddel summary dari hasil analisis regresi linier berganda di atas. Berdasarkan output akan diperoleh angka $R$ Square.

- Uji t (Parsial)

Uji t digunakan untuk mengetahui masing-masing sumbangan variabel bebas secara parsial terhadap variabel terikat, menggunakan uji masing-masing koefisien regresi variabel bebas apakah mempunyai pengaruh yang signifikan atau tidak terhadap variabel terikat.

\section{HASIL DAN PEMBAHASAN}

\section{- Uji Validitas}

Berikut ini adalah hasil pengujian validitas variabel motivasi dengan menggunakan bantuan software SPSS 23.0:

\section{Variabel Harga $\left(\mathbf{X}_{1}\right)$}

\begin{tabular}{|l|l|l|l|l|}
\hline Pernyataan & r hitung & r table & Sig (2-tailed) & Kesimpulan \\
\hline 1 & 0,349 & 0,238 & 0,013 & Valid \\
\hline 2 & 0,666 & 0,238 & 0,000 & Valid \\
\hline 3 & 0,623 & 0,238 & 0,000 & Valid \\
\hline 4 & 0,748 & 0,238 & 0,000 & Valid \\
\hline 5 & 0,603 & 0,238 & 0,000 & Valid \\
\hline 6 & 0,334 & 0,238 & 0,018 & Valid \\
\hline 7 & 0,605 & 0,238 & 0,001 & Valid \\
\hline 8 & 0,437 & 0,238 & 0,002 & Valid \\
\hline 9 & 0,681 & 0,238 & 0,000 & Valid \\
\hline 10 & 0,400 & 0,238 & 0,004 & Valid \\
\hline
\end{tabular}


Variabel Distribusi $\left(\mathbf{X}_{2}\right)$

\begin{tabular}{|l|l|l|l|l|}
\hline Pernyataan & $\mathrm{r}$ hitung & $\mathrm{r}$ tabel & Sig (2-tailed) & Kesimpulan \\
\hline 1 & 0,752 & 0,238 & 0,000 & Valid \\
\hline 2 & 0,745 & 0,238 & 0,000 & Valid \\
\hline 3 & 0,760 & 0,238 & 0,000 & Valid \\
\hline 4 & 0,746 & 0,238 & 0,001 & Valid \\
\hline 5 & 0,739 & 0,238 & 0,000 & Valid \\
\hline 6 & 0,704 & 0,238 & 0,000 & Valid \\
\hline 7 & 0,741 & 0,238 & 0,000 & Valid \\
\hline 8 & 0,766 & 0,238 & 0,000 & Valid \\
\hline 9 & 0,747 & 0,238 & 0,000 & Valid \\
\hline 10 & 0,652 & 0,238 & 0,003 & Valid \\
\hline
\end{tabular}

Variabel Promosi $\left(\mathbf{X}_{3}\right)$

\begin{tabular}{|l|l|l|l|l|}
\hline Pernyataan & r hitung & r table & Sig (2-tailed) & Kesimpulan \\
\hline 1 & 0,607 & 0,238 & 0,001 & Valid \\
\hline 2 & 0,716 & 0,238 & 0,000 & Valid \\
\hline 3 & 0,694 & 0,238 & 0,000 & Valid \\
\hline 4 & 0,462 & 0,238 & 0,001 & Valid \\
\hline 5 & 0,805 & 0,238 & 0,000 & Valid \\
\hline 6 & 0,604 & 0,238 & 0,000 & Valid \\
\hline 7 & 0,708 & 0,238 & 0,000 & Valid \\
\hline 8 & 0,702 & 0,238 & 0,000 & Valid \\
\hline 9 & 0,693 & 0,238 & 0,000 & Valid \\
\hline 10 & 0,621 & 0,238 & 0,000 & Valid \\
\hline
\end{tabular}

Variabel Keputusan Pembelian (Y)

\begin{tabular}{|l|l|l|l|l|}
\hline Pernyataan & r hitung & r tabel & Sig (2-tailed) & Kesimpulan \\
\hline 1 & 0,659 & 0,238 & 0,000 & Valid \\
\hline 2 & 0,537 & 0,238 & 0,000 & Valid \\
\hline 3 & 0,615 & 0,238 & 0,000 & Valid \\
\hline 4 & 0,585 & 0,238 & 0,000 & Valid \\
\hline 5 & 0,550 & 0,238 & 0,000 & Valid \\
\hline 6 & 0,558 & 0,238 & 0,000 & Valid \\
\hline 7 & 0,794 & 0,238 & 0,000 & Valid \\
\hline 8 & 0,736 & 0,238 & 0,000 & Valid \\
\hline 9 & 0,707 & 0,238 & 0,000 & Valid \\
\hline 10 & 0,770 & 0,238 & 0,000 & Valid \\
\hline
\end{tabular}

- Uji Reliabilitas

Hasil Uji Reliabilitas Variabel Harga $\left(\mathbf{X}_{1}\right)$

Reliability Statistics

\begin{tabular}{|l|l|}
\hline $\begin{array}{l}\text { Cronbach's } \\
\text { Alpha }\end{array}$ & $\mathrm{N}$ of Items \\
\hline, 730 & 10 \\
\hline
\end{tabular}


Berdasarkan hasil analisis pada di atas diketahui bahwa nilai Cronbach's Alpha $>0,6$ atau 0,730>0,6 sehingga item-item pernyataan dari variable harga $\left(X_{1}\right)$ adalah reliabel. Berdasarkan keputusan tersebut, maka semua item pernyataan dari variabel harga bisa digunakan sebagai instrument atau tidak ada yang diperbaiki atau dihilangkan.

\section{Hasil Uji Reliabilitas Variabel Distribusi $\left(\mathbf{X}_{2}\right)$}

Reliability Statistics
\begin{tabular}{|l|l|}
\hline $\begin{array}{l}\text { Cronbach's } \\
\text { Alpha }\end{array}$ & N of Items \\
\hline, 900 & 10 \\
\hline
\end{tabular}

Berdasarkan hasil analisis pada tabel di atas di atas diketahui bahwa nilai Cronbach's Alpha $>0,6$ atau 0,900 > 0,6 sehingga item-item pernyataan dari variable distribusi $\left(\mathrm{X}_{2}\right)$ adalah sangat reliabel. Berdasarkan keputusan tersebut, maka semua item pernyataan dari variable pelatihan bisa digunakan sebagai instrument atau tidak ada yang diperbaiki atau dihilangkan.

\section{Hasil Uji Reliabilitas Variabel Promosi $\left(\mathbf{X}_{3}\right)$}

\section{Reliability Statistics}

\begin{tabular}{|l|l|}
\hline $\begin{array}{l}\text { Cronbach's } \\
\text { Alpha }\end{array}$ & N of Items \\
\hline, 855 & 10 \\
\hline
\end{tabular}

Berdasarkan hasil analisis pada tabel di atas diketahui bahwa nilai Cronbach's Alpha $>0,6$ atau 0,855 $>0,6$ sehingga item-item pernyataan dari variabel promosi $\left(\mathrm{X}_{3}\right)$ adalah sangat reliabel. Berdasarkan keputusan tersebut, maka semua item pernyataan dari variabel budaya lingkungan bisa digunakan sebagai instrument atau tidak ada yang diperbaiki atau dihilangkan.

\section{Hasil Uji Reliabilitas Variabel Keputusan Pembelian (Y)}

\section{Reliability Statistics}

\begin{tabular}{|l|l|}
\hline $\begin{array}{l}\text { Cronbach's } \\
\text { Alpha }\end{array}$ & $\mathrm{N}$ of Items \\
\hline, 852 & 10 \\
\hline
\end{tabular}

Berdasarkan hasil analisis pada tabel 4.11 diketahui bahwa nilai Cronbach's Alpha >0,6 atau 0,852 > 0,6 sehingga item-item pernyataan dari variabel Kinerja Karyawan (Y) adalah sangat reliabel. Berdasarkan keputusan tersebut, maka semua item pernyataan dari variabel kinerja karyawan bisa digunakan sebagai instrument atau tidak ada yang diperbaiki atau dihilangkan.

\section{- Uji Asumsi Klasik}

Uji asumsi klasik merupakan uji prasyarat jika anda menggunakan analisis regresi linier. Uji ini antara lain adalah uji normalitas, uji multikolinearitas, uji heteroskedastisitas, dan uji autokorelasi. Jika asumsi tersebut dilanggar, misal model regresi tidak normal, terjadi multikolinearitas, terjadi heteroskedastisitas atau terjadi autokorelasi. Maka hasil analisis rergresi dan pengujian seperti uji t dan uji $\mathrm{F}$ menjadi tidak valid atau bias. Berikut akan dibahas masing-masing uji asumsi klasik regresi sebagai berikut:

\section{Uji Normalitas}

Uji normalitas digunakan untuk menguji apakah data terdistribusi secara normal atau tidak. Pengujian yang digunakan untuk menguji normalitas data yaitu dengan menggunakan analisa grafik P-P plot dan uji One Sample Kolmogorov Smirnov, seperti yang tampak pada gambar di bawah ini: 


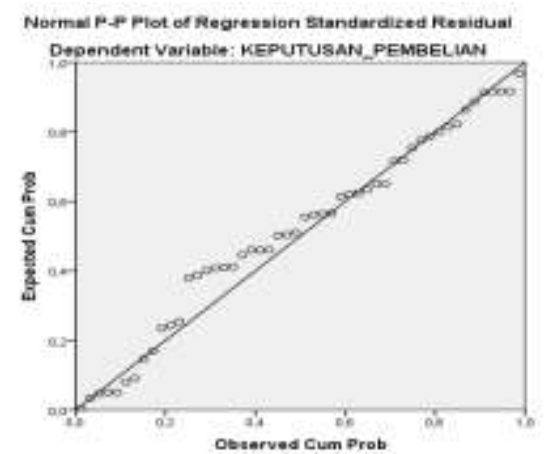

Hasil Uji One Sample Kolmogorov Smirnov

One-Sample Kolmogorov-Smirnov Test

\begin{tabular}{|c|c|c|c|c|c|}
\hline & & HARGA & DIISTRIBUSI & PROMOSI & $\begin{array}{l}\text { KEPUTUSAN_ } \\
\text { PEMBELIAN }\end{array}$ \\
\hline \multirow{3}{*}{$\begin{array}{l}\text { N } \\
\text { Normal Parameters }\end{array}$} & & 50 & 50 & 50 & 50 \\
\hline & Mean & 39,88 & 40,00 & 37,92 & 33,68 \\
\hline & Std. Deviation & 5,029 & 5,095 & 5,022 & 5,773 \\
\hline \multirow[t]{3}{*}{ Most Extreme Differences } & Absolute &, 114 &, 120 & , 130 & ,074 \\
\hline & Positive & 110 & 120 & 130 & ,074 \\
\hline & Negative &,- 114 &,- 080 &,- 121 &,- 044 \\
\hline Test Statistic & & 114 & 120 & 130 &, 074 \\
\hline Asymp. Sig. (2-tailed) & & $123^{\mathrm{c}}$ &, $069^{\mathrm{c}}$ &, $035^{\mathrm{c}}$ & $200^{\mathrm{c}, \mathrm{d}}$ \\
\hline
\end{tabular}

a. Test distribution is Normal.

b. Calculated from data.

c. Lilliefors Significance Correction.

$\mathrm{d}$. This is a lower bound of the true significance.

Berdasarkan pada tabel di atas dapat diketahui bahwa nilai signifikansi (Asymp. Sig 2 tailed) untuk variabel harga 0,123 , distribusi 0,069 , promosi 0,35 dan keputusan pembelian sebesar 0,200 . Karena signifikansi keempat variabel lebih besar dari 0,005, maka dapat disimpulkan bahwa distribusi data pada keempat variabel tersebut dinyatakan normal.

\section{Uji Multikolinearitas}

\section{Hasil Uji Multikolinearitas}

\section{Coefficients $^{\mathrm{a}}$}

\begin{tabular}{|c|c|c|c|c|c|c|c|c|}
\hline \multirow{2}{*}{\multicolumn{2}{|c|}{ Model }} & \multicolumn{2}{|c|}{$\begin{array}{l}\text { Unstandardize } \\
\text { d Coefficients }\end{array}$} & \multirow{2}{*}{ 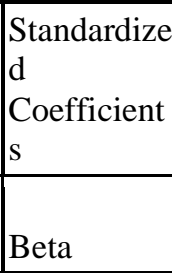 } & \multirow[b]{2}{*}{$t$} & \multirow[b]{2}{*}{ Sig. } & \multicolumn{2}{|c|}{$\begin{array}{l}\text { Collinearity } \\
\text { Statistics }\end{array}$} \\
\hline & & B & $\begin{array}{l}\text { Std. } \\
\text { Error }\end{array}$ & & & & $\begin{array}{l}\text { Toleranc } \\
\mathrm{e}\end{array}$ & VIF \\
\hline & (Constant) & , 106 & 6,791 & & ,016 & ,988 & & \\
\hline & HARGA &, 002 &, 125 &, 002 &, 014 & ,989 & ,964 & 1,038 \\
\hline & DISTRIBUSI &, 681 &, 142 &, 601 & 4,792 &, 000 &, 732 & 1,367 \\
\hline & PROMOSI &, 166 & 145 &, 144 & 1,143 &, 259 &, 723 & 1,383 \\
\hline
\end{tabular}

a. Dependent Variable: Keputusan Pembelian

Berdasarkan hasil fpengujian multikolinearitas yang tampak pada di atas, dapat dilihat pada tabel Coefficients (nilai Tolerance dan VIF) bahwa dari tiga variabel bebas dapat diketahui nilai VIF kurang dari 10 dan nilai Tolerance lebih besar dari 0,1, maka dapat disimpulkan bahwa model regresi tidak terjadi masalah multikolinearitas. 


\section{Uji Heteroskedastisitas}

Heteroskedastisitas merupakan keadaan dimana terjadi ketidaksamaan varian dari residual semua pengamatan pada model regresi. Cara mendeteksinya adalah dengan menggunakan metode grafik, yaitu dengan melihat pola titik-titik pada scatterplot regresi sehingga uji heteroskedasitisitas ini menghasilkan pola penyebaran titik-titik seperti yang tampak pada gambar di bawah ini:

\section{Hasil Uji Heteroskedastisitas}

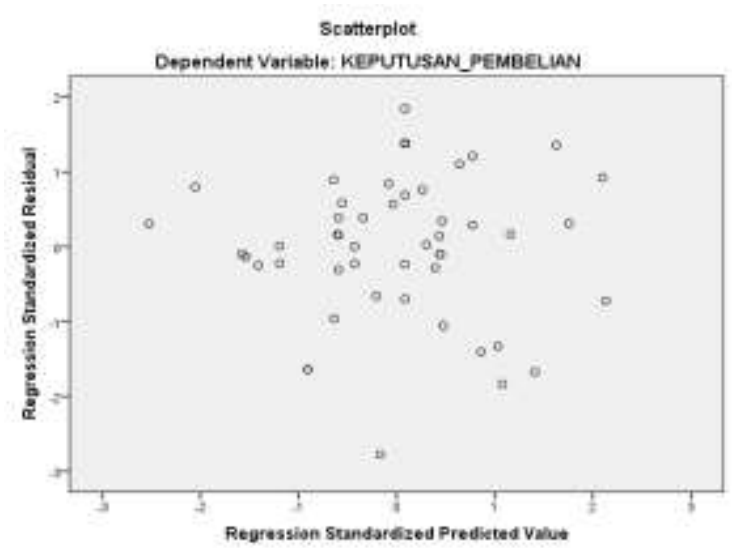

Berdasarkan hasil uji heteroskedastisitas yang terlihat pada gambar di atas menunjukkan bahwa titiktitik tidak membentuk pola tertentu atau tidak ada pola yang jelas serta titik-titik menyebar di atas dan di bawah angka 0 pada sumbu $\mathrm{Y}$, jadi dapat disimpulkan bahwa tidak terjadi masalah heteroskedastisitas pada model regresi.

\section{- Analisis Regresi Berganda}

Analisa regresi yang digunakan adalah analisis linear berganda karena variabel yang digunakan lebih dari satu variabel dengan tingkat signifikansi yang digunakan adalah $5 \%(\alpha=0.05)$. Model ini digunakan untuk mengetahui pengaruh harga, distribusi dan promosi terhadap keputusan pembelian. Berikut adalah tabel yang menerangkan persamaan regresi dalam penelitian ini.

\section{Hasil Analisis Regresi Berganda}

\section{Coefficients $^{\mathrm{a}}$}

\begin{tabular}{|ll|l|l|l|l|l|}
\hline \multicolumn{2}{|c|}{} & \multicolumn{2}{|l|}{ Unstandardized Coefficients } & $\begin{array}{l}\text { Standardized } \\
\text { Coefficients }\end{array}$ & & \\
\cline { 3 - 5 } Model & B & Std. Error & Beta & T & Sig. \\
\hline 1 & (Constant) &, 106 & 6,791 & &, 016 &, 988 \\
& HARGA &, 002 &, 125 &, 002 &, 014 &, 989 \\
& DISTRIBUSI &, 681 &, 142 &, 601 & 4,792 &, 000 \\
& PROMOSI &, 166 &, 145 &, 144 & 1,143 &, 259 \\
\hline
\end{tabular}

a. Dependent Variable: Keputusan Pembelian(Y)

Apabila dari hasil tabel di atas tersebut dimasukkan dalam bentuk persamaan regresi berganda adalah sebagai berikut:

$$
\begin{aligned}
& Y=\alpha+\beta_{1} X_{1}+\beta_{2} X_{2}+\beta_{3} X_{3}+e \\
& Y^{\prime}=0,106+0,002 X_{1}+0,681 X_{2}+0,166 X_{3}
\end{aligned}
$$

Jika dilihat dari persamaan regresi berganda di atas dapat dijelaskan sebagai berikut:

1. Koefisien regresi variabel harga sebesar 0,002 artinya jika variabel harga mengalami kenaikan satu satuan, maka keputusan pembelian akan mengalami peningkatan sebesar 0,002 satuan dengan asumsi variabel bebas lainnya bernilai tetap. 
2. Koefisien regresi variabel distribusi sebesar 0,681 artinya jika variabel distribusi mengalami kenaikan satu satuan, maka keputusan pembelian akan mengalami peningkatan sebesar 0,681 satuan dengan asumsi variabel bebas lainnya bernilai tetap.

3. Koefisien regresi variabel promosi sebesar 0,166 artinya jika variabel promosi mengalami kenaikan satu satuan, maka keputusan pembelian akan mengalami peningkatan sebesar 0,166 satuan dengan asumsi variabel bebas lainnya bernilai tetap.

\section{- Koefisien Korelasi (R) dan Koefisien Determinasi $\left(\mathbf{R}^{2}\right)$}

\section{Hasil Uji Analisis R dan $\mathbf{R}^{2}$}

Model Summary ${ }^{\mathbf{b}}$

\begin{tabular}{|l|l|l|l|l|}
\hline Model & $\mathrm{R}$ & R Square & Adjusted R Square & $\begin{array}{l}\text { Std. Error of the } \\
\text { Estimate }\end{array}$ \\
\hline 1 &, $686^{\mathrm{a}}$ &, 471 &, 437 & 4,333 \\
\hline
\end{tabular}

a. Predictors: (Constant), Promosi (X3), Distribusi (X2), Harga (X1)

b. Dependent Variable: Keputusan Pembelian (Y)

Berdasarkan model summary pada tabel di atas diketahui nilai $\mathrm{R}=0,686$, maka nilai tersebut menggambarkan tingkat hubungan yang kuat antara variabel harga, distribusi dan promosi terhadap keputusan pembelian. Sedangkan untuk koefisien determinasi dilihat dari angka pada Adjusted RSquare sebesar 0,437, hal ini menunjukkan bahwa persentase sumbangan pengaruh variabel bebas yaitu harga, distribusi dan promosi dapat memberikan kontribusi pengaruh sebesar 43,7\% terhadap variabel terikat keputusan pembelian dan sisanya 56,3\% dipengaruhi oleh variabel lain yang tidak dimasukkan dalam model penelitian ini.

\section{- Uji Hipotesa}

\section{Uji t ( Parsial )}

\section{a. Variabel Harga $\left(\mathbf{X}_{1}\right)$}

Berdasarkan pada tabel 4.16 diperoleh $t_{\text {hitung }}$ untuk variabel harga $\left(X_{1}\right)$ yaitu sebesar 0,014 . Dengan menggunakan tabel distribusi t yang dicari pada $\alpha=5 \%$ dan signifikasi 0,025 (uji 2 sisi) dengan df (degree of freedom) 50-3-1 = 46, maka hasil diperoleh untuk $\mathrm{t}_{\text {tabel }}$ sebesar 2,012. Karena nilai $\mathrm{t}_{\text {hitung }}$ $<\mathrm{t}_{\text {tabel }}(0,014<2,012)$ dengan nilai sig $(0,989)$ maka Ho diterima dan Ha ditolak, artinya bahwa harga $\left(\mathrm{X}_{1}\right)$ secara parsial tidak berpengaruh signifikan terhadap keputusan pembelian $(\mathrm{Y})$.

b. Variabel Distribusi $\left(\mathbf{X}_{2}\right)$

Berdasarkan pada tabel 4.16 diperoleh $t_{\text {hitung }}$ untuk variabel distribusi $\left(\mathrm{X}_{2}\right)$ yaitu sebesar 4,792. Dengan menggunakan tabel distribusi t yang dicari pada $\alpha=5 \%$ dan signifikasi 0,025 (uji 2 sisi) dengan df (degree of freedom) 50-3-1 = 46, maka hasil diperoleh untuk $\mathrm{t}_{\text {tabel }}$ sebesar 2,012. Karena nilai $t_{\text {hitung }}>t_{\text {tabel }}(4,792>2,012)$ dengan nilai sig $(0,000)$ maka Ho ditolak dan Ha diterima, artinya bahwa distribusi $\left(\mathrm{X}_{2}\right)$ secara parsial berpengaruh signifikan terhadap keputusan pembelian $(\mathrm{Y})$.

c. Variabel Promosi $\left(\mathbf{X}_{3}\right)$

Berdasarkan pada tabel 4,16 diperoleh $t_{\text {hitung }}$ untuk variabel promosi $\left(\mathrm{X}_{3}\right)$ yaitu sebesar 1,143 . Dengan menggunakan tabel distribusi t yang dicari pada $\alpha=5 \%$ dan signifikasi 0,025 (uji 2 sisi) dengan df (degree of freedom) 50-3-1=46, maka hasil diperoleh untuk $\mathrm{t}_{\text {tabel }}$ sebesar 2,012. Karena nilai $t_{\text {hitung }}>t_{\text {tabel }}(1,143<2,012)$ dengan nilai sig $(0,259)$ maka Ho diterima dan Ha ditolak, artinya bahwa promosi $\left(\mathrm{X}_{3}\right)$ secara parsial tidak berpengaruh signifikan terhadap keputusan pembelian $(\mathrm{Y})$.

\section{Uji F}

\section{Hasil Analisa Regresi Uji F}

ANOVA $^{\mathrm{a}}$

\begin{tabular}{|ll|l|l|l|l|l|}
\hline Model & & Sum of Squares & df & Mean Square & F & Sig. \\
\hline 1 & Regression & 769,267 & 3 & 256,422 & 13,658 &, $000^{\mathrm{b}}$ \\
& Residual & 863,613 & 46 & 18,774 & & \\
& Total & 1632,880 & 49 & & & \\
\hline
\end{tabular}

a. Dependent Variable: KEPUTUSAN_PEMBELIAN

b. Predictors: (Constant), PROMOSI, HARGA, DISTRIBUSI 
Berdasarkan tabel di atas diketahui nilai F-Sig. adalah 0,000 artinya bahwa $p$-value $<\alpha$ atau $0,000<$ 0,05 sehingga keputusan yang diambil adalah Ho ditolak dan Ha diterima. Hal ini menunjukan bahwa secara bersama-sama (simultan) terdapat pengaruh yang signifikan antara motivasi, pelatihan dan budaya lingkungan secara bersama-sama terhadap kinerja karyawan. Sedangkan jika penentuan keputusan dengan cara mebandingkan $\mathrm{F}_{\text {hitung }}$ dengan $\mathrm{F}_{\text {tabel }}$. Pada tabel diatas diperoleh $\mathrm{F}_{\text {hitung }}$ sebesar 13,658, dengan menggunakan tingkat keyakinan 95\%, $\alpha=5 \%$, df1 atau $4-1=3$ dan df 2 atau 50-3-1 $=46$, maka hasil yang diperoleh untuk $F_{\text {tabel }}$ sebesar 2,574. Karena $F_{\text {hitung }}>F_{\text {tabel }}(13,658>2,574)$ maka Ho ditolak dan Ha diterima yang artinya harga, disribusi dan promosi secara bersama-sama berpengaruh signifikan terhadap keputusan pembelian.

\section{PEMBAHASAN}

Uji reliabilitas menunjukkan bahwa nilai Cronbach Alpha dari tiap-tiap variabel lebih besar dari 0,60 yang berarti bahwa kuesioner yang merupakan indikator-indikator dari variabel tersebut adalah reliabel atau handal. Hal tersebut dapat dilihat dari hasil pengujian yang telah dilakukan sebagai berikut: variabel harga (X1) nilai Cronbach Alpha sebesar 0,730, distribusi (X2) sebesar 0,900, promosi (X3) sebesar 0,855 dan keputusan pembelian (Y) sebesar 0,852 .

Uji validitas menunjukkan bahwa nilai $r$ hitung dari masing-masing variabel lebih besar dari $r$ tabel sebesar 0,238 dan tingkat signifikansi dari masing-masing pernyataan kurang dari 0,05 dengan hasil pengujian yang telah dilakukan sebagai berikut:

\section{Untuk variabel harga $\left(X_{1}\right)$}

Indikator pertanyaan kesatu $\mathrm{r}$ hitungnya sebesar 0,349 , pertanyaan kedua sebesar 0,666, pertanyaan ketiga sebesar 0,623 , pertanyaan keempat sebesar 0,748 , pertanyaan kelima sebesar 0,603 , pertanyaan keenam sebesar 0,334 , pertanyaan ketujuh sebesar 0,605 , pertanyaan kedelapan sebesar 0,437, pertanyaan kesembilan sebesar 0,681, dan pertanyaan kesepuluh sebesar 0,400.

\section{Untuk variabel distribusi $\left(\mathbf{X}_{2}\right)$}

Indikator pertanyaan kesatu $r$ hitungnya sebesar 0,752 , pertanyaan kedua sebesar 0,745 , pertanyaan ketiga sebesar 0,760, pertanyaan keempat sebesar 0,746, pertanyaan kelima sebesar 0,709 , pertanyaan keenam sebesar 0,704 , pertanyaan ketujuh sebesar 0,741 , pertanyaan kedelapan sebesar 0,766, pertanyaan kesembilan sebesar 0,747, dan pertanyaan kesepuluh sebesar 0,682.

\section{Untuk variabel promosi $\left(\mathbf{X}_{3}\right)$}

Indikator pertanyaan kesatu $r$ hitungnya sebesar 0,607, pertanyaan kedua sebesar 0,716, pertanyaan ketiga sebesar 0,694 , pertanyaan keempat sebesar 0,462 , pertanyaan kelima sebesar 0,805 , pertanyaan keenam sebesar 0,604 , pertanyaan ketujuh sebesar 0,708 , pertanyaan kedelapan sebesar 0,702, pertanyaan kesembilan sebesar 0,693, dan pertanyaan kesepuluh sebesar 0,621.

\section{Untuk variabel keputusan pembelian (Y)}

Indikator pertanyaan kesatu $r$ hitungnya sebesar 0,659, pertanyaan kedua sebesar 0,537, pertanyaan ketiga sebesar 0,615 , pertanyaan keempat sebesar 0,585 , pertanyaan kelima sebesar 0,550 , pertanyaan keenam sebesar 0,588 , pertanyaan ketujuh sebesar 0,794 , pertanyaan kedelapan sebesar 0,736, pertanyaan kesembilan sebesar 0,707, dan pertanyaan kesepuluh sebesar 0,770.

Hasil pengujian hipotesis dijelaskan sebagai berikut:

\section{Pengaruh harga terhadap keputusan pembelian.}

Hasil pengujian hipotesis 1 mendapatkan bahwa variabel harga secara parsial tidak memiliki pengaruh yang signifikan terhadap keputusan pembelian. Hal ini dapat ditunjukkan dengan nilai $\mathrm{t}_{\text {hitung }}<\mathrm{t}_{\text {tabel }}(0,014<2,012)$.

\section{Pengaruh distribusi terhadap keputusan pembelian.}

Hasil pengujian hipotesis 2 mendapatkan bahwa variabel distribusi secara parsial memiliki pengaruh yang signifikan terhadap keputusan pembelian. Hal ini dapat ditunjukkan dengan nilai $t_{\text {hitung }}>t_{\text {tabel }}(4,792>2,012)$.

\section{Pengaruh promosi terhadap keputusan pembelian.}

Hasil pengujian hipotesis 3 mendapatkan bahwa variabel promosi secara parsial tidak memiliki pengaruh yang signifikan terhadap keputusan pembelian. Hal ini dapat ditunjukkan dengan $\mathrm{t}_{\text {hitung }}<\mathrm{t}_{\text {tabel }}(1,143<2,012)$. 
Berdasarkan dari hasil uji $\mathrm{F}$ memperlihatkan bahwa pengaruh secara bersamaan atau simultan dari seluruh variabel bebas (harga, distribusi dan promosi) terhadap keputusan pembelian pada PT Enseval Putera, menunjukkan hasil yang signifikan. Hal tersebut ditunjukkan dari besarnya nilai $\mathrm{F}_{\text {hitung }}>\mathrm{F}_{\text {tabel }}$ yaitu 13,658 $>$ 2,934 dengan tingkat signifikansi 0,000 (kurang dari 0,05).

\section{KESIMPULAN}

Berdasarkan uraian-uraian yang telah penulis paparkan terhadap data penelitian yang telah terkumpul kemudian diolah mengenai pengaruh harga, distribusi dan promosi pada PT Enseval Putera, maka penulis dapat menarik beberapa kesimpulan sebagai berikut:

> Hasil analisis regresi berganda menunjukkan bahwa variabel harga tidak memiliki pengaruh yang signifikan terhadap keputusan pembelian obat batuk komix pada PT Enseval Putera Hal ini dapat ditunjukkan dengan nilai $\mathrm{t}_{\text {hitung }}<\mathrm{t}_{\text {tabel }}(0,014<2,012)$, dengan nilai sig $(0,989)$ maka Ho diterima dan Ha ditolak, artinya bahwa harga $\left(\mathrm{X}_{1}\right)$ secara parsial tidak berpengaruh signifikan terhadap keputusan pembelian (Y).

$>$ Hasil analisis regresi berganda menunjukkan bahwa variabel distribusi memiliki pengaruh yang signifikan terhadap keputusan pembelian obat batuk komix pada PT Enseval Putera Hal ini dapat ditunjukkan dengan nilai $t_{\text {hitung }}>t_{\text {tabel }}(4,792>2,012)$, dengan nilai sig $(0,000)$ maka Ho ditolak dan Ha diterima, artinya bahwa distribusi $\left(\mathrm{X}_{2}\right)$ secara parsial berpengaruh signifikan terhadap keputusan pembelian (Y).

$>$ Hasil analisis regresi berganda menunjukkan bahwa variabel promosi tidak memiliki pengaruh yang signifikan terhadap keputusan pembelian obat batuk komix pada PT Enseval Putera Hal ini dapat ditunjukkan dengan $t_{\text {hitung }}<t_{\text {tabel }}(1,143<2,012)$, dengan nilai sig $(0,259)$ maka Ho diterima dan Ha ditolak, artinya bahwa promosi $\left(\mathrm{X}_{3}\right)$ secara parsial tidak berpengaruh signifikan terhadap keputusan pembelian (Y).

$>$ Hasil analisis regresi uji $\mathrm{F}$ menunjukkan bahwa variabel harga, disribusi dan promosi secara bersama-sama berpengaruh signifikan terhadap keputusan pembelian obat batuk komix pada PT Enseval Putera Hal ini dapat ditunjukkan dengan $F_{\text {hitung }}>F_{\text {tabel }}(13,658>2,574)$ serta nilai signifikasi 0,000 lebih kecil dari 0,005 .

$>$ Hasil estimasi dari model regresi dalam penelitian ini menunjukkan bahwa variabel-variabel independen yang ada mampu menjelaskan jumlah keputusan pembelian sebesar 43,7\%, sedangkan sisanya $56,3 \%$ dijelaskan oleh faktor lain yang tidak trmasuk dalam penelitian ini.

\section{REFERENSI}

Basu, Swastha., 2013. Manajemen Penjualan. Edisi ketiga. BPFE, Yogyakarta.

Bilson, Simamora., 2012. Panduan Riset Dan Perilaku Konsumen. PT Gramedia Pustaka Utama, Jakarta.

Danang, Sunyoto., 2015. Perilaku Konsumen dan Pemasaran. CAPS, Yogyakarta.

Kotler, Philip dan Gary Armstrong., 2014. Principle Of Marketing. Edisi kelima belas. Pearson Prentice Hall, New Jersey.

dan Kevin Lane Keller., 2012. Marketing Management. Edisi ketiga belas. Erlangga, Jakarta.

Kotler, Philip., Dasar-Dasar Pemasaran. Edisi kesembilan. Jilid 1, dialihbahasakan oleh Alexander Sindoro. 2012. PT Indeks, Jakarta.

., Manajemen Pemasaran. diterjemahkan oleh Benyamin Molan. 2012. Edisi kesebelas,

Jilid II. PT. Indeks Gramedia, Jakarta.

., 2012. prinsip-prinsip pemasaran. Edisi ketiga belas. Erlangga, Jakarta

Morissan, M. A., 2015. Komunikasi Pemasaran Terpadu. Kencana Prenada Media Group, Jakarta.

Mulyadi, Nitisusastro., 2013. Perilaku Konsumen dalam perspektif kewirausahaan. Alfabeta, Bandung.

Stanton, William J., 2012. Prinsip Pemasaran. Jilid I. Erlangga, Yogyakarta.

Sugiyono., 2015. Metode Penelitian Bisnis (Pendekatan Kuantitatif, Kualitatif dan R\&D). Alfabeta, Bandung. 